\title{
Motivasi Widyaiswara Dalam Penulisan Karya Tulis Ilmiah Pada Badan Pengembangan Sumber Daya Manusia Provinsi Jambi
}

\author{
Asnofidal \\ Badan Pengembangan Sumber Daya Manusia Provinsi Jambi \\ E-mail: asnofidal@gmail.com
}

\begin{abstract}
ABSTRAK
Pembuatan karya tulis ilmiah merupakan bagian dari tugas dan kewajiban bagi widyaiswara, karena mereka berfungsi sebagai pengembang sumber daya manusia aparatur sipil negara. Membuat karya tulis ilmiah memerlukan motivasi yang kuat, karena ia merupakan tugas yang memerlukan konsentrasi penuh. Penelitian ini tentang motivasi widyaiswara Badan Pengembangan Sumber Daya Manusia (BPSDM) Provinsi Jambi untuk membuat karya tulis ilmiah. Data diperoleh melalui Wawancara, Observasi, Focus Group Siscussion (FGD) dan Studi Pustaka. Informan dipilih secara porpusive sampling dan dianalisis dengan metode trianggulasi. Hasil penelitian memperoleh bahwa widyaiswara BPSDM Provinsi Jambi memiliki motivasi instrinsik untuk membuat karya tulis ilmiah yang muncul dari dalam dirinya sendiri, yaitu untuk peningkatan kompetensi diri, karir dan kenaikan pangkat. Selain itu, widyaiswara juga memiliki motivasi ekstrinsik untuk membuat karya tulis ilmiah, yaitu dukungan lingkungan yang nyaman, fasilitas atau sarana dan prasarana yang cukup, dan dukungan kebijakan pimpinan BPSDM Provinsi Jambi dengan berbagai program dan ketersediaan anggaran. Dalam rangka meningkatkan motivasi widyaiswara BPSDM Provinsi Jambi untuk membuat karya tulis ilmiah perlu disarankan beberapa hal sebagai berikut: pengaturan jadwal widyaiswara untuk mengajar secara struktural, sehingga setiap tahun widyaiswara dapat menghasilkan karya tulis ilmiah, mengikutserta widyaiswara dalam setiap kegiatan pertemuan ilmiah seperti seminar dan konferensi baik di dalam daerah maupun di luar daerah, menyediakan anggaran penelitian dan pembuatan karya tulis ilmiah, dan sangat penting memasukkan karya tulis ilmiah sebagai beban kinerja widyaiswara yang harus dimuatkan dalam Sasaran Kinerja Pegawai (SKP).
\end{abstract}

Kata kunci: Widyaiswara, karya tulis ilmiah, motivasi, kompetensi, sumber daya manusia.

\section{PENDAHULUAN}

Widyaiswara merupakan salah satu "Pilar" yang sangat penting dalam keberhasilan penyelenggaraan Diklat. Peraturan Pemerintah Nomor 101 tahun 2000 tentang Pendidikan dan Pelatihan Jabatan PNS disebutkan bahwa widyaiswara merupakan salah satu komponen tenaga kediklatan yang sangat penting disamping komponen lainnya (lembaga Diklat, program Diklat dan penyelenggaraan Diklat) dalam penyelenggaraan Diklat Pemerintah. Dalam pendidikan dan pelatihan bagi aparatur sipil Negara.

Guna mendukung tugasnya Widyaiswara harus memiliki kompetensi transfer of knowledge dan transfer of value dalam proses pembelajaran dalam kediklatan. Salah satu cara untuk mencapai komptensi diri, widyaiswara dituntut membuat Karya Tulis Ilmiah (KTI). Perkembangan kedepan melalui penyusunan karya Tulis Ilmiah, diharapkan para widyaiswara benar-benar dapat terdorong untuk memperkaya wawasan dan memperdalam penguasaan bidang yang diampu dalam lingkup kediklatan.

Berdasarkan laporan Tim Penilai Angka kredit pada Badan Pengembangan Sumber Daya Manusia (BPSDM) Provinsi Jambi tahun 2018, usulan angka kredit widyaiswara berupa Karya Tulis Ilmiah hanya dalam bentuk makalah yang diseminarkan di instansi, bukan artikel yang dipulikasi di jurnal ilmiah. Ini artinya hingga tahun 2018, belum ada karya tulis ilmiah yang dibuat oleh widyaiswara BPSDM Provinsi Jambi yang telah dipublikasikan di jurnal-jurnal ilmiah.

Pembuatan karya tulis ilmiah memerlukan motivasi yang kuat, karena ia merupakan tugas yang memerlukan konsentrasi penuh dan waktu yang luang. Latif, dkk (2016) mengungkapkan bahwa motivasi bertujuan untuk pemenuhan kebutuhan yang akan 
menimbulkan perubahan perilaku seseorang. Konsep ini, diperkuat oleh Robbins (2013) ${ }^{2}$ mendefinisikan motivasi sebagai proses yang dilakukan oleh individu sebagai upaya untuk memperoleh intensitas, arah, dan ketekunan dalam rangka mencapai suatu tujuan. Oleh karena itu, motivasi dapat mempengaruhi kompetensi dan kinerja seseorang, sebagaimana Kristina Nugi Keran $(2012)^{3}$ dari hasil penelitiannya pada Yayasan Bintang Timur Tangerang, mengungkapkan bahwa motivasi sangat berpengaruh terhadap kompetensi dan kinerja karyawan.

Gagne (2009) ${ }^{4}$ mengungkapkan bahwa motivasi terdiri dari dua jenis yaitu motivasi intrinsic (intrinsic motivation) dan motivasi ekstrinsik (extrinsic motivation). Abraham (2010) mengungkapkan bahwa motivasi intrinsik adalah motivasi yang berasal dari dalam individu, yang berarti seseorang melakukan suatu tindakan tidak berdasarkan dari dorongan-dorongan atau faktor-faktor lain yang berasal dari luar diri, contohnya self actualization need (keinginan untuk mengaktualisasikan diri). Sedangkan motivasi ekstrinsik adalah motivasi ekstrinsik merupakan motivasi yang berasal dari luar diri seseorang atau dari luar suatu lingkungan pekerjaan, karena adanya pengaruh faktor-faktor lain dari luar itulah yang menyebabkan rangsangan dari luar menjadi motivasi.

Kedua motivasi tersebut dapat mempengaruhi kinerja dan prestasi seseorang. Hal ini sebagaimana Lilis Maghfuroh (2010) ${ }^{6}$ hasil penelitiannya mengungkapkan bahwa motivasi berpengaruh terhadap prestasi belajar siswa pada semester pendek mata kuliah keperawatan anak II di STIKES Muhammadiyah Lamongan. Selanjutya, Ayu Lestari (2017) mengungkapkan hasil penelitiannya bahwa motivasi intrinsik dan motivasi ekstrinsik berpengaruh positif terhadap prestasi anak didik. Kenyataan ini juga diperkuat oleh Ainun Nida`a (2017), ${ }^{8}$ dari hasil penelitiannya mengemukakan bahwa Motivasi Intrinsik dan ekstrinsik berpengaruh posisitif terhadap Kinerja Petugas Kesehatan di Daerah Kepulauan (Studi Kasus Puskesmas Pulau Barrang Lompo)

Oleh karena itu, peneliti tertarik melakukan penelitian tentang motivasi widyaiswara BPSDM Provinsi Jambi untuk membuat karya tulis ilmiah.

\section{METODE PENELITIAN}

Metode yang digunakan dalam penelitian ini adalah metode kualitatif, yakni menggambarkan secara kualitatif motivasi widyaiswara dalam penulisan karya tulis ilmiah pada Badan Pengembangan Sumberdaya Manusia Provinsi Jambi. Data diperoleh melalui Wawancara, Observasi, Focus Group Siscussion (FGD) dan Studi Pustaka. Informan dipilih secara porpusive sampling yaitu para widyaiswara, Kepala BPSDM Provinsi Jambi sebagai pengambil kebijakan, Sekretaris BPSDM, Kasubbag umum, kasubbag program, Kasubbag Keuangan sebagai pelaksana kebijakan yang terkait dengan widyaiswara.

Data dianalisis melalui tahapan-tahapan analisis dengan cara Coding, Catagories, Trianggulation, dan Conclussion. Penelitian ini dilakukan di Badan Pengembangan Sumberdaya manusia Provinsi Jambi dan Penelitian ini direncanakan kurang lebih selama 3 (tiga) bulan yaitu direncanakan dimulai di bulan April sampai dengan bulan Mei 2019.

\section{HASIL DAN PEMBAHASAN}

\subsection{Motivasi Instrinsik/Job Content/Motivator}

Dari data yang diperoleh, bahwa semua informan memahami tentang Karya Tulis Ilmiah dan mereka tertarik membuatnya karena merupakan salah satu tugas dan fungsi widyaiswara serta merupakan salah satu sumber point penambahan angka kredit untuk kenaikan pangkat. Selain itu, ia merupakan salah satu syarat untuk kenaikan pangkat untuk promosi ke widyaiswara utama. Kemudian informan juga menjawab bahwa penulisan karya tulis ilmiah dapat dijadikan 
wahana pengembangan kreatifitas dan menambah wawasan serta pengalaman dalam menulis, hal ini sebagaimana Sutoro (22/04/2019) mengungkapkan bahwa "penulisan karya tulis ilmiah bagi widyaiswara sangat bermanfaat, disamping untuk penambahan point angka kredit, ia juga sebagai wahana penyaluran kreatifitas".

Membuat karya tulis ilmiah masih dianggap berat dan menjadi beban bagi widyaiswara, hal ini dibuktikan dengan jawaban sebagian besar mereka yang menyatakan sulit, berat dan menjadi beban, sebagaimana Hamid (22/04/2019) mengungkapkan

"pembuatan karya tulis ilmiah menjadi penambahan beban bagi mereka, karena memerlukan waktu dan konsentrasi yang penuh dalam membuatnya, sementara mereka tidak memiliki waktu yang cukup karena hampir setiap hari mereka disibukkan dengan tugas mengajar baik di provinsi maupun di kabupaten/kota"(Hamid).

Pembuatan karya tulis ilmiah tidak memberi kepuasan bagi sebagian besar informan, karena menjadi beban bagi mereka meskipun ada sedikit yang mengatakan suatu kepuasan, karena mereka sudah mampu menunjukkan hasil karya mereka. Penulisan karya tulis ilmiah bagi widyaiswara adalah sangat bermanfaat secara langsung terhadap tugas mereka, semua informan menjawab demikian. Hal ini sebagaimana Ismail (23/04/2019) mengungkapkan bahwa:

"penulisan karya tulis ilmiah sangat bermanfaat secara langsung dengan tugas utama mereka, karena penulisan karya tulis ilmiah disamping tugas wajib juga sebagai sarana pengembangan wawasan dan peningkatan pengetahuan. Penulisan karya tulis ilmiah pada dasarnya memuat pemikiran kritis terhadap isu yang sedang berkembang"(Ismail).

Semua informan menjawab bahwa penulisan karya tulis ilmiah sangat bepengaruh bagi capaian karir widyaiswara ke depan. Bailah (23/04/2019) mengungkapkan bahwa:

"pembuatan karya tulis ilmiah sangat bermanfaat bagi peningkatan karir widyaiswara, karena dengan adanya usaha penulisan karya tulis ilmiah pengambangan wawasan dan pengetahuan widyaiswara akan bertambah, selain itu karya tulis ilmiah dapat dijadikan bahan penambahan angka kredit untuk kenaikan pangkat."

Para widyaiswara sangat memerlukan karya tulis ilmiah, karena merupakan aspek penilaian yang harus dipenuhi sebagai unsur pengembangan profesi, akan tetapi pengalaman mereka dalam penulisan ilmiah masih kurang. Hal ini sebagaimana Lailatul Isnaini (23/04/19) mengungkapkan bahwa:

"widyaiswara sangat memerlukan karya tulis ilmiah, karena ia merupakan salah satu unsur pengembangan profesi, namun pengalaman dalam penulisan ilmiah masih kurang, dan mereka masih belum memahami secara struktur format penulisan ilmiah dengan baik. Oleh karena itu, peningkatan pengetahuan penulisan ilmiah bagi widyaiswara perlu ditingkatkan dengan mengikutsertakan mereka ke dalam diklat dan lokakarya penulisan ilmiah" (Lailatul Isnaini).

Penulisan karya tulis ilmiah secara karir dan kompetensi sangat berpengaruh terhadap peningkatan karir, sebagaimana Bailah (23/04/19) mengungkapkan bahwa:

"tidak membuat karya tulis ilmiah bagi widyaiswara akan berdampak pada terlambatnya kenaikan pangkat, karena nilai pada karya tulis ilmiah yang dipublikasi pada salah satu jurnal akan memberi angka kredit yang tinggi. Jadi, semakin banyak widyaiswara mempublikasi karya tulis ilmiahnya pada salah satu publikasi ilmiah, semakin cepat pula mereka naik pangkat"(Bailah). 
Semua informan menjawab bahwa widyaiswara memiliki kesempatan untuk lebih berkembang jika banyak menulis karya ilmiah, karena dengan karya tulis ilmiah para widyaiswara dapat memperoleh ilmu dan pengetahuan baru yang update sebagai modal pengembangan karir dalam menjalankan tugas kewidyaiswaraan. Bailah (22/04/19) juga menjelaskan bahwa:

"penulisan karya tulis ilmiah memungkinkan widyaiswara memiliki kesempatan untuk berkembang, karena dengan penulisan ilmiah dapat menambah wawasan, pengetahuan dan menemukan solusi baru terhadap persoalan atau permasalahan pemerintahan dan pembangunan nasional dan daerah"(Bailah).

Dari hasil jawaban informan, sebagian besar widayaiswara pada Badan Pengembangan Sumber Daya Manusia Provinsi Jambi belum memiliki karya tulis ilmiah. Hanya terdapat beberapa orang yang menjawab sudah ada, hal ini dibuktikan bahwa Ibuk Enadarlita sudah pernah mempublikasikan karya tulis ilmiahnya pada salah satu publikasi ilmiah.

Dari beberapa jawaban informan di atas, dapat diurutkan sejumlah faktor dari sisi internal yang menjadi pendorong widyaiswara untuk membuat karya tulis ilmiah, di antaranya yaitu:

1) Unsur wajib bagi tugas pokok dan fungsi widyaiswara

2) Sebagai unsur penambahan angka kredit untuk kenaikan pangkat

3) Sebagai wadah peningkatan kompetensi, pengetahuan, wawasan dan keterampilan.

Sedangkan faktor-faktor penghambat bagi widyaiswara untuk membuat karya tulis ilmiah, di antaranya adalah:

1) Keterbatasan waktu untuk fokus membuat karya tulis ilmiah, karena sebagian besar waktu habis digunakan untuk mengisi materi pada diklat, baik di Provinsi Jambi maupun di seluruh kabupaten/kota.

2) Tidak terbiasanya bagi widyaiswara dalam membuat karya tulis ilmiah, sehingga mereka masih kaku dalam memulai dan mengerjakannya.

Dari data diperoleh di atas, widyaiswara BPSDM Provinsi Jambi memiliki motivasi yang muncul dari dalam dirinya sendiri, sebagaimana, Sherif dalam Ahmadi (2007), ${ }^{9}$ motivasi seperti ini adalah motivasi biogenetis (Biogenic Motive), yakni motivasi yang berasal dari kebutuhan biologis sebagai makhluk yang hidup, muncul dari dalam diri individu dan tidak banyak tergantung pada lingkungan diluar individu itu. Ia tumbuh dan berkembang dengan sendirinya atau secara alami di dalam diri individu.

Sungguhpun minat dan keinginan widyaiswara tinggi untuk membuat karya tulis ilmiah, namun mereka menghadapi masalah dengan waktu yang sangat terbatas untuk merelisasikannya. Jumlah widyaiswara di BPSDM Provinsi Jambi sebanyak 22 orang, jumlah ini masih sedikit bila dibandingkan dengan beban kerja yang harus mereka lakukan. Dimana sebanyak 11 (sebelas) pemerintah kabupaten/kota se Provinsi Jambi yang melaksanakan Kediklatan menggunakan jasa para widyaiswara BPSDM Provinsi Jambi. Hal ini tentunya membuat para widyaiswara harus mengatur waktu dengan baik, sehingga hampir tidak ada waktu yang kosong atau luang bagi mereka selain melaksanakan tugas kediklatan.

Pada dasarnya, penulisan karya tulis ilmiah membawa pengaruh bagi pencapaian karir para widyaiswara di masa depan, karena dengan penulisan ilmiah, wawasan dan pengetahuan mereka akan bertambah. Selain itu juga bepengaruh bagi capaian karir widyaiswara ke depan. Hal ini sebagaimana merujuk kepada Peraturan Kepala Lembaga Admnistrasi Negara Nomor 26 tahun $2015,{ }^{10}$ Bab III point 4 menyebutkan bahwa karya tulis ilmiah merupakan sub unsur pengembangan profesi, dengan karya ilmiah bertujuan memperkenalkan dan atau menyebarluaskan ilmu pengetahuan dan teknologi yang bersifat kontemporer atau aktual.

Sementara widyaiswara sebagai penyebar luas ilmu, sangat memerlukan pengetahuan yang maju dan up to date, sehingga ilmu atau materi yang diberikan kepada peserta diklat tidak 
ketinggalan zaman dan tetap menarik dan baru. Dengan demikian, para widyaiswara BPSDM Provinsi Jambi sangat tertarik dan berminat sekali untuk membuat karya tulis ilmiah. Robbins (2013) mengungkapkan pencapaian prestasi, tanggung jawab, kemajuan, pekerjaan itu sendiri, dan kemungkinan berkembang yang keberadaannya menyebabkan kepuasan dan membentuk motivasi yang kuat yang menghasilkan prestasi kerja yang baik. Senada dengan itu, Siagean $(2010)^{11}$ mengungkapkan bahwa kebutuhan aktualisasi diri (self-actualization), yakni keinginan untuk tumbuh, berkembang, dan merealisasikan potensi merupakan motivasi yang muncul dari dalam diri indivuidu.

Bobbi \& Porter (2000) ${ }^{12}$ juga mengemukakan bahwa kondisi yang ada pada diri individu yang berhubungan dengan munculnya motivasi yang ada pada diri karyawan dalam situasi kerjanya. Motivasi seringkali muncul dalam diri karyawan, baik yang berhubungan dengan ekonomi, tujuan pribadi maupun sikap. Adanya motivasi akan membuat semangat kerjanya meningkat sehingga prestasi kerjanya juga akan meningkat.

Berdasarkan uraian di atas, dapat disimpulkan bahwa motivasi intrinsik widyaiswara untuk membuat karya tulis ilmiah sangat tinggi. Hal ini disebabkan bahwa karya tulis ilmiah adalah salah satu syarat untuk meningkatkan karir, pangkat dan sebagai wadah pengembangan ilmu dan wawasan yang up to date.

\subsection{Motivasi Ektrinsik/Job Context/Hygiene Factor}

Berbagai faktor yang mempengaruhi motivasi widyaiswara untuk membuat karya tulis ilmiah diantaranya pengaruh lingkungan kerja. Lingkungan yang nyaman dapat mendukung meningkatkan konsentrasi dan fokus widyaiswara untuk membuat karya tulis ilmiah, jauh dari kebisingan dan terhindar dari hiruk pikuk keramaian dan gangguan oarng yang tidak diinginkan.

Pertanyaan tentang hal ini sebagian besar informan menjawab sudah nyaman sebagaimana hasil wawancara dengan Lailatul Isnaini (22/04/2019) yang mengungkapkan bahwa:

"kondisi lingkungan Badan Pengembangan Sumber Daya Manusia Provinsi Jambi pada dasarnya sudah memadai dan sudah nyaman, karena posisi ruang widyaiswara jauh dari kebisingan masyarakat ramai, jauh dari jalan raya dan dikelilingi ruang kelas belajar" (Lailatul Isnaini).

Badan Pengembangan Sumber Daya Manusia Provinsi Jambi berada dalam kawasan dengan luas 7 ha yang terletak di Jalan H. Agus Salim kawasan Kecamatan Kota Baru Kota Jambi, dengan jarak $7 \mathrm{~km}$ dari pusat Kota Jambi dan $1 \mathrm{~km}$ dari komplek perkantoran Walikota Jambi. Letak gedung BPSDM berada pinggir jalan yang dikelilingi oleh tanaman dan pepohonan dengan suasana asri dan sejuk. Posisinya jauh dari kebisingan dan keramaian masyarakat serta sangat terhindar gangguan keributan dan stress. Hal ini, merupakan lingkungan yang sangat mendukung bagi widyaiswara untuk konsentrasi penuh dan fokus untuk membuat tugas terutama karya tulis ilmiah.

Dalam hal sarana dan prasarana pendukung bagi widyaiswara untuk membuat karya tulis ilmiah, sebagian besar informan menjawab sudah memadai. Hal ini dibuktikan dengan tersedianya ruangan dengan ukuran $10 \mathrm{~m}$ x $14 \mathrm{~m}$, yang cukup menampung widyaiswara yang berjumlah 22 orang dengan meja dan kursi yang cukup, almari penyimpanan barang, dilengkapi mesin pendingin (AC), dan tersdianya ruang tamu. Sebagaimana Lailatul Isnaini (22/04/2019) mengungkapkan bahwa:

"Badan Sumber Daya manusia Provinsi Jambi pada dasarnya sudah memiliki sarana dan prasarana pendukung bagi widyaiswara untuk membuat karya tulis ilmiah, seperti tersedianya perpustakaan sebagai bahan rujukan, adanya wifi atau 
sinyal internet yang cukup memadai dan dapat diakses oleh widyaiswara”. (Lailatul Isnaini).

Berdasarkan observasi di lapangan, untuk meningkatkan kompetensi widyaiswara BPSDM Provinsi Jambi dalam pembuatan karya tulis ilmiah, telah terdapat beberapa sarana dan prasarana pendukung, yaitu sebagai berikut:

1) Ruang perpustakaan

Ruangan kerja yang nyaman sangat penting bagi widyaiswara untuk mengerjakan kegiatan pembuatan karya tulis ilmiah, agar widyaiswara dapat fokus dan konsentrasi untuk bekerja.

Ruang perpustakaan telah didirikan sejak tahun 2014 dengan ukuran ruangan $15 \mathrm{~m} \mathrm{x}$ $20 \mathrm{~m}$, dan telah diisikan berbagai macam buku bacaan atau literatur dan laporan proyek perubahan peserta diklat.

2) Saluran internet

Jaringan internet sangat penting dalam mendukung pembuatan karya tulis ilmiah, guna memudahkan widyaiswara mendapatkan rujukan atau sumber literature dan data lainnya. Sejak tahun 2010, BPSDM Provinsi Jambi telah memiliki saluran internet dengan menggunakan Wireless Fidelity (WIFI) menggunakan saluran PT Telkom. Saluran ini dapat dapat diakses secara gratis dan dapat terjangkau di seluruh kawasan BPSDM Provinsi Jambi.

Uraian di atas diperkuat oleh Kepala BPSDM Provinsi Jambi H. M. Iskandar Nasution (27/04/2019) mengungkapkan:

"untuk kemudahan aparatur sipil negara BPSDM Provinsi Jambi, terutama dalam rangka pengembangan kompetensi widyaiswara, BPSDM telah menyediakan ruang perpustakaan yang nyaman, yang dilengkapi dengan berbagai buku leteratur, saluran

Wireless Fidelity (WIFI), sebagai sarana ASN untuk mudah mendapatkan informasi dan berkomunikasi dengan pihak lain"(Iskandar Nasution).

Sherif dalam Ahmadi (2007) mengemukakan bahwa motivasi dapat timbul dari dalam diri individu karena adanya hubungan dan interaksi dengan lingkungan sekitarnya, hal ini disebut dengan motivasi Sosiogenetis (Sociogenic Motive). Selanjutnya, Bobbi \& Porter (2000) mengungkapkan bahwa lingkungan kerja yang mendukung dapat menjadi salah satu faktor penting dalam memotivasi karyawan meningkat. Karakteristik situasi kerja adalah apa yang terjadi pada karyawan dalam pekerjaannya. Terdapat dua variabel yaitu lingkungan sosial yang langsung, misalnya atasan atau rekan kerja dan berbagai tipe tindakan yang diambil oleh organisasi, misalnya imbalan, kompetensi dan iklim organisasi.

Berdasarkan uraian di atas, motivasi ekstrinsik lingkungan dan sarana prasarana widyaiswara untuk membuat karya tulis ilmiah sangat mendukung. Di antara factor-faktor pendukungnya adalah ruangan yang nyaman, lingkungan yang sejuk dan jauh dari kebisingan, tersedianya jaringan internet dan terdapat ruang perpustakaan.

\subsection{Kebijakan Pimpinan}

Sebagai seorang pimpinan adalah suatu kewajiban untuk mendukung peningkatan komptensi anggotanya. Hasibuan (2006) ${ }^{13}$ mengungkapkan bahwa seorang pimpinan harus memberikan motivasi positif (insentif positif) kepada bawahannya dengan memberikan hadiah kepada mereka yang berprestasi baik. Dengan motivasi positif ini semangat kerja bawahan akan meningkat, karena manusia pada umumnya senang menerima yang baik-baik saja.

Badan Pengembangan Sumber Daya Manusia Provinsi Jambi sangat berperan dalam usaha peningkatan profesi widyaiswara. Iskandar (27/04/2019) menjelaskan bahwa dalam 
rangka mewujudkan usaha tersebut, BPSDM telah membuat berbagai kebijakan, di antaranya yaitu:

1) Mengadakan Diklat Penulisan karya tulis ilmiah (DPA BPSDM Tahun 2019), tertuang pada kegiatan sub bagian program sekretriat. Dalam Rencana Kegiatan disebutkan bahwa kegiatan pembuatan karya tulis ilmiah bagi widyaiswara. Tenaga pengajar dalam kegiatan ini adalah dosen dari perguruan tinggi, tenaga ahli dari pusat yang telah berpengalaman menulis dan mempublikasaikan karya tulis Ilmiah.

2) Menganggarkan biaya peningkatan kompetensi bagi setiap widyaiswara untuk mengikuti pertemuan ilmiah, seperti seminar, konferensi, dan lain sebagainya, baik dalam daerah maupu di luar daerah (DPA BPSDM Tahun 2019), tertuang pada kegiatan sub bagian program sekretariat. Setiap widyaiswara berhak mendapatkan anggaran tersebut sesuai dengan kebutuhannya.

3) Pada tahun 2019, telah menganggarkan kegiatan penerbitan jurnal ilmiah (DPA BPSDM Tahun 2019), telah keluar Surat Keputusan Kepala BPSDM Nomor /SK/Ka-BPSDM/04/2019 tentang susunan tim penyusun Jurnal BPSDM Provinsi Jambi tentang.

Ungkapan di atas diperkuat oleh Sutoro (22/04/2019) bahwa:

"Badan Pengembangan Sumber Daya Manusia Provinsi Jambi sudah banyak mendukung bagi widyaiswara untuk membuat karya tulis ilmiah, hal ini dibuktikan dengan adanya Diklat penulisan karya tulis ilmiah yang dilakukan setiap tahun, dan telah dianggarkan pembuatan jurnal ilmiah sebagai wadah untuk menyalurkan atau publikasi karya tulis ilmiah yang dimilki oleh widyaiswara”(Sutoro).

Akan tetapi, dukungan teman kerja widyaiswara BPSDM Provinsi Jambi untuk membuat karya tulis ilmiah masih lemah, hal ini dibuktikan bahwa sebagian besar informan menjawab bahwa dukungan teman kerja untuk membuat karya tulis ilmiah masih lemah, lingkungan pertemanan di tempat kerja belum memberikan suasana/dukungan positif yang membuat widyaiswara mampu menulis karya tulis ilmiah. Hamid Madjid (22/03/2019) mengungkapkan: "pengakuan yang bersifat objektif dari atasan dan rekan kerja belum diperoleh oleh rekan yang telah membuat karya tulis ilmiah, perhatian dan pandangan rekan kerja dianggap biasa saja dan tidak dianggap hal yang berprestasi atau nilai lebih"(Hamid Madjid).

Selain itu, belum adanya pengawasan yang dilakukan oleh pimpinan dalam pelaksanaan kegiatan menulis karya tulis ilmiah oleh widyaiswara. Iskandar (27/04/2019) mengungkapkan: "pihak pimpinan BPSDM belum melakukan pengawasan secara terstruktur terhadap widyiswara, apakah mereka telah membuat karya tulis ilmiah atau belum. Urusan ini diserahkan sepenuhnya kepada widyaiswara masing-masing untuk mengatur tugas mereka masing-masing, karena hal ini tidak perlu dilakukan pengawasan yang ketat, karena karya tulis ilmiah merupakan kewajiban bagi widyaiswara dalam rangka peningkatan kompetensi dan pangkat mereka. Pihak pimpinan BPSDM hanya menyediakan sarana dan prasarana, anggaran untuk mempermudah dan mengurangi beban mereka untuk membuat karya tulis ilmiah" (Iskandar).

Gibson, Ivancevich, Donelly (2012) ${ }^{14}$ mengemukakan kondisi ekstrinsik (konteks pekerjaan) yang meliputi mutu pengawasan, upah, keamanan kerja, kondisi kerja, status, prosedur perusahaan, mutu hubungan interpersonal antar sesama rekan kerja, atasan, dan bawahan yang keberadaannya tidak selalu memotivasi, tetapi ketidakberadaanya menyebabkan ketidakpuasan karyawan. 
Selain itu, Bobbi \& Porter (2000), mengemukakan bahwa dalam hubungannya dengan faktor yang mempengaruhi motivasi yang dimaksud lingkungan kerja ialah pemimpin dan bawahan. Dari pihak pemimipin ada berbagai unsur yang sangat berpengaruh terhadap motivasi, seperti kebijakan-kebijakan yang telah ditetapkan, termasuk didalamnya prosedur kerja, berbagai rencana dan program kerja. Persyaratan kerja yang perlu dipenuhi oleh bawahan. Tersedianya seperangkat alat-alat dan sarana yang diperlukan di dalam mendukung pelaksanaan kerja, termasuk di dalamnya bagaimana tempat para bawahan bekerja. Gaya kepemimpinan atasan dalam arti sifat-sifat dan perilaku atasan terhadap bawahan.

Dari uraian di atas dapat disimpulkan bahwa, pimpinan Badan Pengembangan Sumber Daya Manusia Provinsi Jambi sangat memotivasi widyaiswara untuk membuat karya tulis ilmiah. Di antara kebijakan yang dibuat adalah program pendidikan dan pelatihan karya tulis ilmiah yang dilaksanakan setiap tahun dengan mendatangkan instruktur dari akademisi. Tersedianya anggaran bagi widyaiswara yang akan mengikuti seminar, konferensi dan pertemuan ilmiah lainnya, baik di dalam daerah maupun di luar daerah. Selanjutnya, telah dianggarkan pembuatan jurnal ilmiah yang diterbitkan BPSDM Provinsi Jambi sebagai wadah untuk menampung tulisan-tulisan ilmiah yang dimiliki oleh widyaiswara.

\section{KESIMPULAN DAN SARAN}

Berdasarkan uraian dan analisis data di atas dapat disimpulkan bahwa semua widyaiswara mengetahui dan memahami tentang Karya Tulis Ilmiah dan mereka tertarik dan sangat berminat terhadapnya, karena membuat karya tulis ilmiah dapat meningkatkan pengetahuan, wawasan dan kompetensi mereka. Ini artinya widyaiswara memiliki motivasi yang muncul dari dalam dirinya sendiri. Beberapa faktor yang mempengaruhi adalah pegembangan, penambahan wawasan dan pengetahuan diri; tanggungjawab dan tugas pokok jabatan; capaian prestasi dan karir serta merupakan sub unsur pengembangan profesi; dan adanya kepuasan dan aktualisasi diri.

Disamping itu, lingkungan BPSDM Provinsi Jambi telah mendukung semangat widyaiswara untuk membuat karya tulis ilmiah. Hal ini didukung dengan adanya fasilitas atau sarana dan prasarana pendukung untuk melaksanakan tugas widyaiswara sudah tersedia, di antara sarana yang tersedia dan mendukung adalah ruangan widyaiswara, jaringan internet, perpustakaan sebagai bahan rujukan dan lingkungan yang nyaman dan jauh dari kebisingan

Pimpinan BPSDM Provinsi Jambi sangat mendukung pembuatan karya tulis ilmiah widyaiswara, di antara bukti dukungan tersebut adalah penganggaran dan program Diklat penulisan karya tulis ilmiah yang dilakukan setiap tahun; mengikutsertakan widyaiswara dalam kegiatan seminar, konfrensi dan pertemuan ilmiah lainnya, baik di dalam daerah maupun di luar daerah; pembuatan jurnal ilmiah sebagai wadah untuk menyalurkan atau publikasi karya tulis ilmiah yang dimiliki oleh widyaiswara.

Namun demikian, untuk meningkatkan motivasi widyaiswara BPSDM Provinsi Jambi untuk membuat karya tulis ilmiah perlu disarankan beberapa hal, seperti perlu dilakukan pengaturan jadwal secara struktural oleh widyaiswara sehingga setiap tahun widyaiswara dapat menghasilkan karya tulis ilmiah. Tak hanya itu, widyaiswara diharapkan dapat ikutserta dalam setiap kegiatan ilmiah seperti seminar, konferensi, dan pertemuan ilmiah lainnya, guna untuk membiasakan diri widyaiswara untuk berpikir teoritis dan praktis serta dapat dituangkan dalam karya tulis ilmiah. Selanjutnya, pihak BPSDM diharapkan dapat meningkatkan anggaran guna membuat program atau kegiatan ilmiah untuk peningkatan kompetensi widyaiswara. Pihak BPSDM Provinsi Jambi agar menyediakan anggaran pendukung sebagai biaya sarana prasaran yang diperlukan dalam penulisan karya tulis ilmiah. Selain itu, penting dimasukkan karya tulis ilmiah sebagai beban kinerja widyaiswara yang harus dimuatkan dalam Sasaran Kinerja Pegawai (SKP). 


\section{DAFTAR PUSTAKA}

1 Latif, Mukhtar, Risnita, Shoffa Saifullah, 2016, Tata Kelola Madrasah Kontemporer, Jambi: Kelompok Studi Penulisan

2 Robbins, Stephen P \& Judge, Timothy A. 2013, Organizational Behavior Edition 15. New Jersey: Pearson Education.

3 Kristina Nugi Keran, 2012, Pengaruh Motivasi Kerja, Kompetensi dan Kompensasi terhadap Kinerja Karyawan di Yayasan Bintang Timur Tangerang, Tesis: Program Pascasarjana, Universitas Eku Unggul Jakarta.

${ }^{4}$ Gagne, Marylene, 2009, A Model of Knowledge-Sharing Motivation. Human Resource Management, 46(4), 571-589. Retrieved from Wiley InterScience Journals Database.

5 Abraham H. Maslow, 2010, Motivation and Personality, Jakarta: Rajawali

${ }^{6}$ Lilis Maghfiroh, 2010, Hubungan Minat dan Motivasi dengan Prestasi Belajar Semester Pendek Mata Kuliah Keperawatan Anak II di STIKES Muhammadiyah Lamongan, Tesis: Program Pascasarjana Universitas Sebelas Maret Surakarta.

7 Ayu Lestari Aziz, 2017, Pengaruh Motivasi Intrinsik dan Motivasi Ekstrinsik terhadap Belajar Ekonomi Bisnis Kelas X Peserta Didik Kelas X SMKN 4 Makassar, Tesis: Program Pascasarjana Universitas Negeri Makassar.

8 Ainun Nida`a, 2017, Pengaruh Motivasi Intrinsik dan Motivasi Ekstrinsik terhadap Kinerja Petugas Kesehatan di Daerah Kepulauan (Studi Kasus Puskesmas Pulau Barrang Lompo), Tesis: Program Pascasarjana Univesitas Hasunuddin Makassar.

9 Abu, Ahmadi, 2007, Psikologi Sosial, Jakarta: Rineka Cipta.

${ }^{10}$ Peraturan Kepala Lembaga Admnistrasi Negara Nomor 26 tahun 2015 Tentang Pedoman Penilaian Angka Kredit Jabatan Fungsional Widyaiswara

11 Siagian, Sondang P. 2001. Peranan Staf dan Manajemen. Penerbit CV. Gunung Agung. Jakarta.

${ }^{12}$ Bobbi dan Porter, 2000, Quantum Teaching/Learning, Bandung: Kaifa

13 Hasibuan, Malayu S.P, 2006, Manajemen Dasar, Pengertian, dan Masalah, Edisi Revisi,(Jakarta: Bumi Aksara.

14 James L. Gibson, John M. Ivancevich, James H Donelly, Organizations : behavior, structure, processes, - 14th ed, (New York: McGraw-Hill, 2012) 